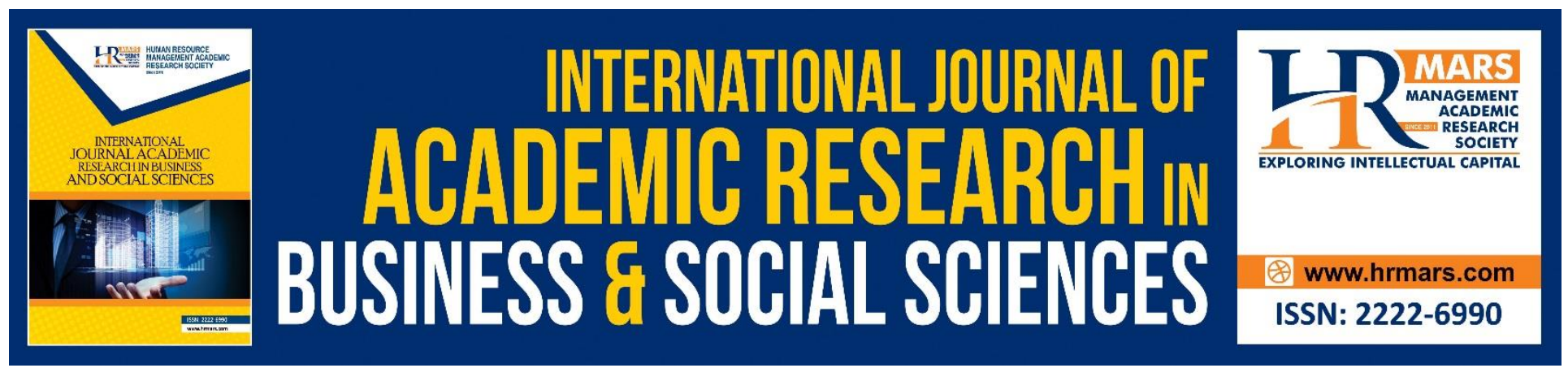

\title{
The Orang Asli Profile in Peninsular Malaysia: Background \& Challenges
}

\begin{abstract}
Noraini Mohd Shah, Ridzwan Che' Rus, Ramlee Mustapha, Mohd Azlan Mohammad Hussain, Norwaliza Abdul Wahab
\end{abstract}

To Link this Article: http://dx.doi.org/10.6007/IJARBSS/v8-i7/4563

DOI: $\quad 10.6007 /$ IJARBSS/v8-i7/4563

Received: 21 May 2018, Revised: 19 June 2018, Accepted: 29 June 2018

Published Online: 17 July 2018

In-Text Citation: (Shah, Rus, Mustapha, Hussain, \& Wahab, 2018)

To Cite this Article: Shah, N. M., Rus, R. C., Mustapha, R., Hussain, M. A. M., \& Wahab, N. A. (2018). The Orang Asli Profile in Peninsular Malaysia: Background \& Challenges. International Journal of Academic Research in Business and Social Sciences, 8(7), 1157-1164.

\section{Copyright: (C) 2018 The Author(s)}

Published by Human Resource Management Academic Research Society (www.hrmars.com)

This article is published under the Creative Commons Attribution (CC BY 4.0) license. Anyone may reproduce, distribute, translate and create derivative works of this article (for both commercial and non-commercial purposes), subject to full attribution to the original publication and authors. The full terms of this license may be seen

at: http://creativecommons.org/licences/by/4.0/legalcode

\section{Vol. 8, No. 7, July 2018, Pg. 1157 - 1164}




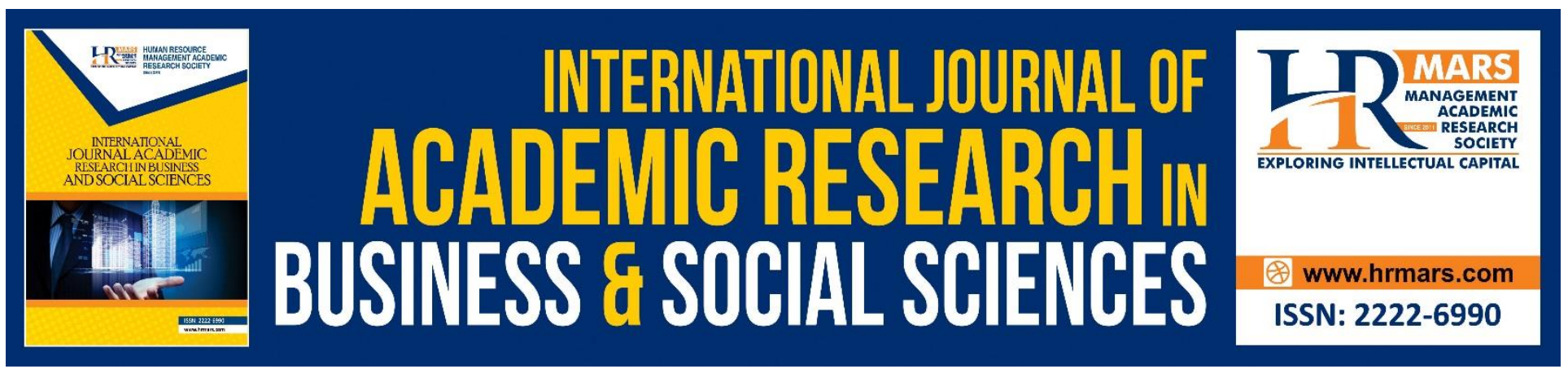

\title{
The Orang Asli Profile in Peninsular Malaysia: Background \& Challenges
}

\author{
Noraini Mohd Shah ${ }^{a^{*}}$, Ridzwan Che' Rus ${ }^{\text {a }}$, Ramlee Mustapha ${ }^{a}$, \\ Mohd Azlan Mohammad Hussain a, Norwaliza Abdul Wahab ${ }^{\text {b }}$ \\ aFaculty of Technical and Vocational, Sultan Idris Education University, 35900 Tanjung Malim, \\ Malaysia \\ ${ }^{b}$ Faculty of Education and Human Development, Sultan Idris Education University, 35900 Tanjung \\ Malim, Malaysia \\ Corresponding Author Email: aini_uum@yahoo.com
}

\begin{abstract}
This paper discusses in general about the background of the Orang Asli community in Peninsular Malaysia, the rights of the Orang Asli and the challenges the Orang Asli community have to face in sustaining indigenous tourism in Peninsular Malaysia. There are three Orang Asli ethnic groups in Peninsular Malaysia which are the Senoi, the Proto-Malay and the Negrito. Each Orang Asli ethnic group is divided into several tribes. Each clan or tribe inhabits the states of Peninsular Malaysia with its own culture and unique way of life. Thus this paper will discuss about the profile of the Orang Asli's community in Peninsular Malaysia from the perspective of the background and challenges of the Orang Asli in Peninsular Malaysia.
\end{abstract}

Keywords: Orang Asli, Peninsular Malaysia, Background, Challenges, Indigenous Tourism Sustainability

\section{Introduction}

Most of the Orang Asli community are descendants of the Hoabinhian that have lived in Peninsular Malaysia as early as 11,000 BC (Bellwood, 1997). The Orang Asli community consists of eighteen cultures and have different sub-groups (Lin, 2008). In 2004 the Orang Asli Affairs Department (JHEOA) made a survey on the estimated number of Orang Asli population in Malaysia which was about 149 723 people (JHEOA, 2006). The population of Orang Asli represents less than $1 \%$ of the total population of Malaysia of 27 million people (Ramlee, 2013). The majority of them live in the forest areas and still practice the traditional ways of living that is influenced greatly by the environment and their ancestral practices. In addition, their living is closely related closely to the natural resources (Zalizan Mohd Jelas, Abdul Razaq Ahmad \& Ahmad Rafaai Ayudin, 2009). Based on the historical perspective on the location of Peninsular Malaysia, over 150, 000 years ago, the jungles of Peninsular Malaysia have been the main route of the Neolithic nomadic tribes who founded the cluster of settlements along the main rivers by depending on the forest resources as their source of living. The 
INTERNATIONAL JOURNAL OF ACADEMIC RESEARCH IN BUSINESS AND SOCIAL SCIENCES Vol. 8, No. 7, July 2018, E-ISSN: 2222-6990 @ 2018 HRMARS

Peninsular Malaysian areas have been acknowledged by historians as among the most fertile area in the world apart from the Amazon and Borneo jungles. Its natural treasures are linked to its equatorial position, which is hot and humid throughout the year (Zalizan Mohd Jelas \& Abdul Razaq Ahmad, Ahmad Rafaai Ayudin, 2009).

\section{Study Background}

Based on the historiography of the Malay community and the Orang Asli community, it was found that both groups did not originate from the same roots. The Orang Asli were a neolithic nomadic tribe that existed around the world from Africa that originated from the Negrito group about 40,000 years ago while the Malay peoples originated from the Yunan Highlands in Southern China. The migration route of nomadic societies from northern Europe to Australia through the Peninsular had existed in the past hundreds of thousand years ago based on the similar remains of historical artifacts left behind at several continents. The inauguration of early settlements in Peninsular Malaysia was a result of major migrations in ancient times from two directions, one of which is from Africa had begun the migration of the Negrito tribal groups and from Yunan two stages of migration, one of which is the Proto-Malay group and the Deutro-Malay group (Zalizan Mohd Jelas \& Abdul Razaq Ahmad, 2009). Table 2.1 shows the Orang Asli Ethnic Groups in Peninsular Malaysia

Table 2.1 Orang Asli Ethnic Groups in Peninsular Malaysia Source: Orang Asli Affairs Department (2010)

\begin{tabular}{ccc}
\hline Senoi & Proto-Malay & Negrito \\
\hline Semai & Temuan & Kensiu \\
Temiar & Semelai & Kintak \\
Jah Hut & Jakun & Jahai \\
Che' Wong & Kanaq & Lanoh \\
Mah Meri & Orang Kuala & Mendriq \\
Semaq Beri & Orang Seletar & Bateq \\
\hline
\end{tabular}

There are roughly 3\% of Negrito Orang Asli tribes from the whole of the Orang Asli peoples and it is the smallest tribal group (JHEOA, 2003). The Negrito Orang Asli tribe are the earliest human group to inhabit Peninsular Malaysia which is roughly 25, 000 years ago (Carey, 1976). Physically, the Negrito Orang Asli tribe are relatively small physically (1.5 meters or less), dark-skinned (dark-bronze to black), frizzy curly-haired, large nosed, have round eyes and low-cheeked. Based on the latest findings by archaeologists, the Negrito tribes are related to the Hoabinh peoples, that lived during the Mesolithic ages, 8000 BC. This assumption is supported by Nocholas (2000) based on the Negrito way of living, where the majority are still nomadic explorers and live at a settlement where the surrounding natural resource is able to support the needs of the group.

The Senoi Orang Asli tribe in Malaysia has settlements in the hillsides of Titiwangsa in the remote areas of Perak, Kelantan and Pahang. There are 6 tribes in the Senoi group of which are the Che Wong, Mahmeri, Jah Hut, Semoq Beri, Semai dan Temiar. Senois are proficient hunters and foragers. The Senoi Orang Asli are the largest Orang Asli community which is $54 \%$ of the total population of Orang Asli in Peninsular Malaysia (JHEOA, 2003; Nicholas, 2000). There are small physical differences between the Senois and Negritos which are the slightly taller physical stature, lighter skinned and wavy hair without curls. 
INTERNATIONAL JOURNAL OF ACADEMIC RESEARCH IN BUSINESS AND SOCIAL SCIENCES

Vol. 8, No. 7, July 2018, E-ISSN: 2222-6990 @ 2018 HRMARS

In addition, part of the group lives in the northern and central part of Peninsular Malaysia and is believed to originate from Mongolia (Zalizan Mohd Jelas \& Abdul Razaq Ahmad, 2009). The Asli Cewong clan, Mah Meri clan, Semai clan, Semoq Beri clan, Temiar clan and Jah Hut clan are examples of the Senoi Orang Asli clans. The Mah Meri clan lives in the Carey Island area and the Pelek river areas in Selangor and are known for their wooden sculptures and fine artwork that is an attraction among tourists. The Mah Meri clan practices animism beliefs and ancestral teachings. There are five Mah Meri Orang Asli villages on Carey Island, which are the Bukit Bangkong village, Sungai Kurau village, Sungai Judah village, Sungai Bumbun village and Sungai Jugra Orang Asli village (Hasan Mat Nor, 1998; Sunaidin, 1997).

The Proto-Malay group originated from the Polynesian Malay group that have settlements near the seas and rivers. Among the Proto-Malay Orang Asli groups are the Orang Kuala, Orang Kanaq, Orang Seletar, Jakun, Semelai and Temuan. The Proto-Malay group is the second largest group which consists of $43 \%$ of the total Orang Asli population in Peninsular Malaysia (JHEOA, 2003; Nicholas, 2000). The Proto-Malay group mostly lives in the southern and central states of Peninsular Malaysia. According to Nicholas (2000), the migration history of the Proto-Malay to the southern states (Johor and Negeri Sembilan) cannot be established accurately due to the lack of records or historical source. However, the Proto-Malay peoples are believed to be part of the Orang Kuala group that migrated from Sumatera about 500 years ago.

Based on the United Nations' estimates, there are roughly 370 million indigenous peoples in the world and two thirds of them live in Asia (United Nations, 2007; UNDP, 2012). Orang Asli are the aboriginal peoples of Peninsular Malaysia since 11,000 BC (Bellwood, 1997). The orang Asli community is estimated to be about 178,197 people which is less than $1 \%$ of the total population of Malaysia of 27 million people (JHEOA, 2012). In 1961, the country's leaders framed a strategic plan to integrate the Orang Asli into the mainstream with the intent of bringing them into the market economy and assimilating them into the Malay ethnic category.

\section{Orang Asli Community Challenges}

The Orang Asli are the minority of the Malaysian population. According to a 2006 survey, the number of Orang Asli is 141, 230 people. The socioeconomic status of a large portion of the Orang Asli community are still lagging in various areas as compared to other races in Malaysia. In terms of the settlement distribution of the Orang Asli, 36.9\% lives in the remote areas, $62.4 \%$ lives in the rural areas and $0.7 \%$ in urban areas. In line with the goals of the Vision 2020 and the New Economic Policy (NEP), the guidelines on Orang Asli have been reviewed towards accelerating the improvement of the socioeconomic level while maintaining their cultural identity. In general, the steps to develop the Orang Asli community are in line with the principles of the Rukun Negara and the goals of the NEP to enable the development process to provide prosperity, security and integration of the Orang Asli with the other communities (JAKOA, 2016). Figure 1.1 shows the settlement distribution of the Orang Asli community in Peninsular Malaysia. 
Figure 3.1 shows the settlement distribution of the Orang Asli community in Peninsular Malaysia.

\section{The Settlement Distribution of the Orang Asli Community in Peninsular Malaysia}

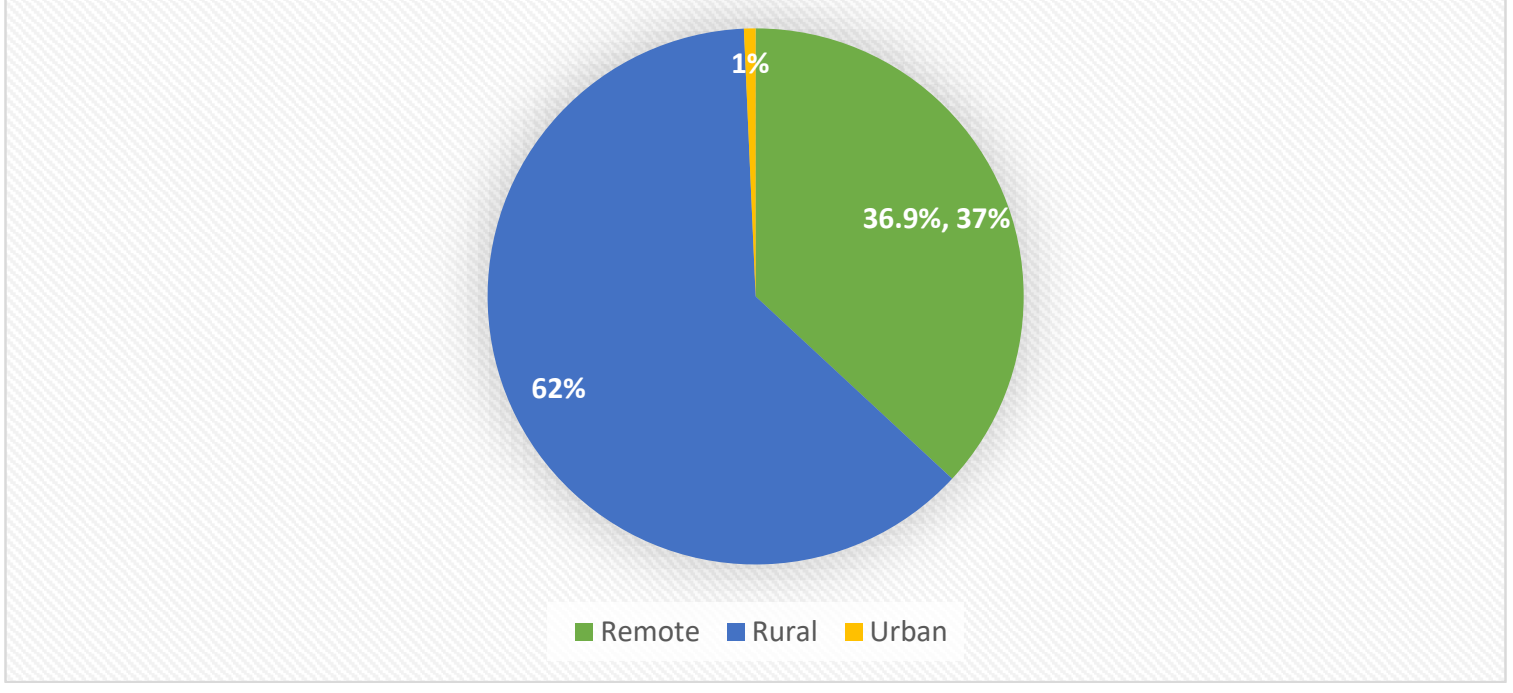

The first challenge of the Orang Asli community is in terms of the backwardness and poverty that is faced by them (Noraida Harun \& Noor' Ashikin Hamid, 2010). In 2009, the Orang Asli community recorded a poverty rate of $49 \%$ which shows that 1 out of 2 Orang Asli are poor at the time (Azlina \& Ma'rof, 2013). For instance research by Norlida et al. (2012) on the village of Sungai Ruil in Cameron Highlands found that the majority of Orang Asli are still in the low income bracket. There are only $1.5 \%$ of the community that earns RM1500 to RM 2000 monthly while the rest earns less than RM1500.

Poverty among the Orang Asli is generally said to be the major component of the national poverty data. In 2006, as many as $33.5 \%$ dan $15.4 \%$ of the Orang Asli had been identified as belonging to the absolute and absolute hardcore poverty groups respectively (Ekonomi Unit Perancangan, 2006). In the Ninth Malaysian Plan (2006-2010), the government allocated RM417,400,000 for various strategies and programs to reduce the absolute and absolute hardcore poverty rate among the Orang Asli including economic programs, relocation initiatives, and other programs intended for human capital development (Bhuiyan et al., 2012). This issue of poverty will also hinder the Orang Asli community development process, and will hamper efforts to integrate the various Orang Asli groups with the nation's flow of progress as realized by other races. Hence in the Tenth Malaysian Plan, the government has targeted to reduce the poverty rate among the Orang Asli community from $50 \%$ in 2009 to $25 \%$ in 2015 (Azlina \& Ma'rof, 2013)<t2/>. Thus, the efforts by the government in developing the Orang Asli effectively is in progress

The second challenge is in terms of the lack of participation and cooperation from the local community to make the indigenous tourism programs a success are among the challenges in sustaining indigenous tourism. In light of this, the engagement and cooperation from the local community especially in matters related to the surrounding environment, for example the forest in 
INTERNATIONAL JOURNAL OF ACADEMIC RESEARCH IN BUSINESS AND SOCIAL SCIENCES Vol. 8, No. 7, July 2018, E-ISSN: 2222-6990 @ 2018 HRMARS

this study, are important as they live in the area and are well-versed and understand the local environment at their homes and indirectly they can give and contribute basic information that are useful to ensure indigenous tourism activities are a success (Nur Atiqah Kamarus Zaman et al., 2014).

The third challenge is in terms of improving the Orang Asli community. Since Malaysia achieved independence in 1957 various efforts had been conducted to improve the Orang Asli community by implementing a variety of economic, social and educational development projects (Carey, 1976; Ramle Abdullah, 2001). The government aims to raise the socioeconomic level of the Orang Asli community that are exteremely low compared to other ethnic groups in the country, via the implementation of the development projects. Current statistics show that more than $80 \%$ of the Orang Asli population are still below the poverty level (Zainal Abidin Haji Ali, 2004). The various Orang Asli tribes and clans have responded in varying degrees to the development programs that had been implemented by the government. Some if the Orang Asli have positive perceptions and are open to such development programs that are proposed. (Ramle Abdullah, 2008).

The fourth challenge is in terms of the traditional Orang Asli way of life that is the main reason why the commnunity is below the poverty level (Suki Mee, 2005). Because of this, the indigenous tourism program is carried out among the Orang Asli community in order to raise the economic level of the Orang Asli community generally. But the attitudes and mindset of the Orang Asli community are the biggest challenges faced by the government in the efforts to develop the Orang Asli community. Various parties have labeled the Orang Asli as a community that is too dependent on government assistance, a community with low self-esteem and modest, lacking in confidence and not appreciative of a productive work culture and possesses low self-resilience in facing outside challenges and competition (Khairul Hisyam \& Ibrahim, 2007). In 2008, as much as RM 320,000 was allocated by the government in building retail spaces for the convenience of the Orang Asli community (Wee et al., 2010). The government provided retail space and workshop utilities to Orang Asli traders or entrepreneurs at locations with the potential to improve retail business, services or manufacture that encompasses the states of Selangor, Malacca, Kelantan and Pahang(Wee et al., 2013). But the facilities of the infrastructure are still at a unsatisfactory level especially the basic amenities, for example the electrical supply. The level of readiness and implementation of facilities of the infrastructure for the purpose of tourism development is still at an unsatisfactory and lackadaisical level. It is made worse by the absence of a integrated program that involves the local community in the ecotourism activity

The fifth challenge is in terms of the academic achievements of the Orang Asli students that is still too low if compared against the achievements of other Malaysian citizens (Toh Kit Siang, 2008). The high dropout rate in education, starting from pre-school all the way to higher education institutions, are from the minority groups of the Orang Asli community (Doris Padmini Selvaratnam, Abdul Hamid Jaafar, Norlida Hanim Mohd Salleh, Redzuan Othman \& Siti Hajar Idris, 2012). A study conducted by Zainal Abidin (2008) shows that the dropout rate of Orang Asli are much higher among the secondary school students as compared to primary school students. This can be seen in 2008 when the academic status of Orang Asli attending secondary schools was about $26 \%$ vs. $74 \%$ of those attending primary schools, and the Orang Asli youths entering the public universities (IPTA) was only 63\% (JAKOA, 2012). 
INTERNATIONAL JOURNAL OF ACADEMIC RESEARCH IN BUSINESS AND SOCIAL SCIENCES

Vol. 8, No. 7, July 2018, E-ISSN: 2222-6990 @ 2018 HRMARS

\section{Conclusion}

The socioeconomic status of the Orang Asli community are still lagging in various areas as compared to other races in Malaysia. Hence, there needs to be further studies with regards to the background of the Orang Asli community in Peninsular Malaysia, the rights of the Orang Asli and the challenges needed to be faced by the Orang Asli community in sustaining indigenous tourism in Peninsular Malaysia.

\section{References}

Awang, S. N., Fadzil, K. S., Suzita, W., Ibrahim, W., Zinol, R., \& Edo, J. (2015). Indigineous tourism Satu tinjauan awal penglibatan masyarakat Orang Asli dalam industri pelancongan Orang Asli (aboriginal) community participation in the tourism industry - A preliminary survey of BelumTemenggor, 9(9), 125-136.

Ah Choy, E., Atan, A., Muhammed, H., Sakawi, Z., \& JH, A. (2012). Analisis Kelebihan Kompetitif Ekopelancongan di Mukim Ulu Dong, Raub, Pahang, Malaysia. [The competitive edge in Malaysian ecotourism: An analysis of Dong, Raub] Geografia - Malaysian Journal of Society and Space, 8(8), 158-169.

Adger, N.W. (2001). Social capital and climate change. Tyndall Centre for Climate Change Research, Working Paper No. 8. October 2001. School of Environmental Sciences, University of East Anglia.

Blowers, A. (1992). Planning a Sustainable Future: Problems, principles and prospects. Journal of Town \& Country Planning.

Drumm, A. (1988). New approaches to Community-Based Ecotourism Management. Learning from Equador. In: Kreg Lindberg, Donald E. Hawkins (eds) Ecotourism: A Guide for Planner \& Managers, pp.197-213. The Ecotourism Society, North Bennington, Vermont.

Kates, R., Parris, T. \& Leiserowitz, A. Harvard. (2005)."What is Sustainable Development? Goals, Indicators, Values, and practice" Environment 47(3): 8-21

Khor, G.L. \& Mohd Shariff, Z. (2008). The ecology of health and nutrition of Orang Asli women and children in Peninsular Malaysia. Tribes and Tribals 2: 67-77

Kementerian Pelancongan Malaysia (MOTOUR) (2013). Available from:http:// www.tourism.gov.my. Lin, C.Y.O. (2008). Autonomy reconstituted: Social and gender implications of resettlement on the Orang Asli of Peninsular Malaysia. In B.P. Resurreccion \& R. Elmhirst (Eds.). Gender and natural resource management: Livelihoods, mobility and interventions, hlm. 21-33. London: Earthscan.

Lehtonen, M. (2004). The environmental-social interface of sustainable development: Capabilities, social capital, institutions. Ecological Economics, 49(2), 199-214. http://doi.org/10.1016/i.ecolecon.2004.03.019

Nordin, R., Hassan, M. S., Ganesan, T., Ahmad, A., \& Balakrishnan, R. (2013). Hak penentuan nasib sendiri orang asal: Kajian kes Orang Asli di Kampung Sungai Bumbun, Pulau Carey. Kanun, 25(1), 43-65.

United Nations General Assembly. (2005). 2005 World Summit Outcome, Resolution A/60/1, adopted by the General Assembly on 15 September 2005.

Rolston, H. (1994). Conserving natural value. Columbia University Press. Chicago

Stone, W., Hughes, J. (2002). Measuring social capital: towards a standardised approach. Paper Presented at the 2002 Australasian Evaluation Society International Conference, Wollongong, Australia, October/November. http://www.aes.asn.au. 
INTERNATIONAL JOURNAL OF ACADEMIC RESEARCH IN BUSINESS AND SOCIAL SCIENCES

Vol. 8, No. 7, July 2018, E-ISSN: 2222-6990 @ 2018 HRMARS

Stone, W., Hughes, J. (2002). Measuring social capital: towards a standardised approach. Paper Presented at the 2002 Australasian Evaluation Society International Conference, Wollongong, Australia, October/November. http://www.aes.asn.au.

UNDP (2012). Indigenous voices in Asia-Pacific: Indentifying the information and communication needs of indigenous peoples.

Wheeler, S.M. (2004). Planning for Sustainability. Routledge

Zeppel, H. (2006). Indigenous ecotourism: Sustainable development and management (Vol. 3). 